\title{
ENERGY SAVING: A CASE STUDY ON “CHANGE ROUTINE, SAVE ENERGY” IN ENGINEERING INSTITUTE
}

\author{
Kuldeep Tiwari ${ }^{1}$, Subhash Misra ${ }^{2}$, Vijay Kr. Dixit ${ }^{3}$ \\ ${ }^{13}$ Department of ECE, Indus Institute of Technology \& Management, Kanpur (India) \\ ${ }^{2}$ Department of ME, Indus Institute of Technology \& Management, Kanpur (India)
}

\begin{abstract}
Saving of energy will always an issue to discuss and to work on. Replacement of obsolete electrical or electronic appliances will no doubt lead to $E$ - waste in India. If we generate or produce energy, three kinds of cost need to be considered Basic cost, Social cost, Environmental cost. So we need a solution which does not create any environment issue. Here we are considering an old Indian thought "Early to bed, early to rise" and making some changes in the daily routine of hostel life of a student without disturbing his general life style and observing the percentage change in Energy consumption per year. Results were really surprising showing minimum consumption without creating any environment crisis and also there is no social impact. This may be the best way to save electricity in future.
\end{abstract}

Key words- Energy, Power, Consumption, Cost, Electricity, Institutes, Environment, Hostel, Rooms, Students, Saving, Conventional, Resource.

\section{INTRODUCTION}

The population of world is increasing by a rate of $1.1 \%$ per year while in India; this rate is $1.2 \%$ per year similar to that of Indonesia. The rate of consumption of Energy is somehow directly dependent on the rate at which population is increasing. In India, thermal power plants are generally used for the production of $66 \%$ of total Electric energy where coal is used primarily as a heating agent that leads to a vast emission of $\mathrm{CO}_{2}, \mathrm{NO}_{2}$ and $\mathrm{SO}_{2}$. The percentage of $\mathrm{CO}_{2}$ is quite high in the thermal generation of Electricity. During thermal generation, the requirement of coal is not going to be fulfilled in future as coal is a conventional resource and will be depleted soon.

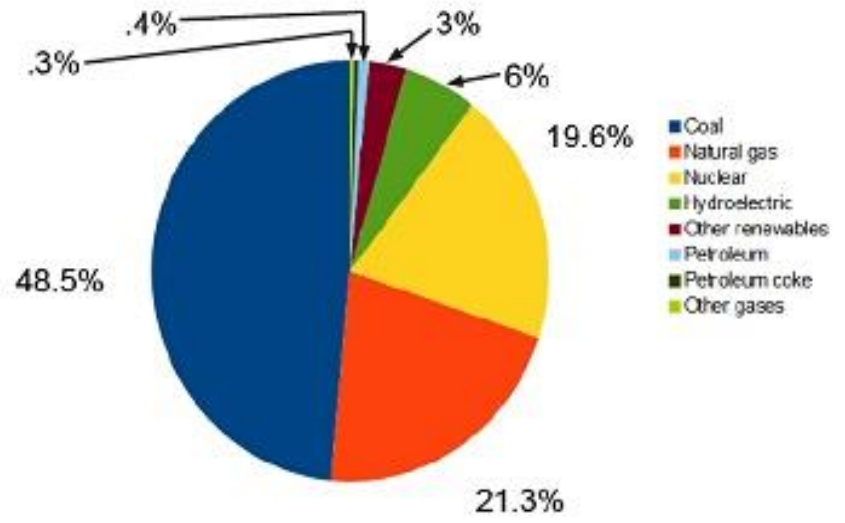

Fig. 1. Conventional resources

India has over $17 \%$ of the world's population and hence a significant consumer of energy resources. India consumes its maximum energy in residential, commercial and agricultural purposes in comparison to developed countries.[1] It is noted that the share of energy consumption in India and China has also been on the raise due to sharp urbanization, population explosion, and intensive growth of IT and related business [2]. Growth and development of any society highly depend on availability of energy. Hence meeting energy demand for the country is an important task for sustainable development of the nation. [1]

The nation's education institutions spend almost $\$ 15$ billion annually on energy. The U.S. Environmental Protection Agency (EPA), through the ENERGY STAR program, offers a proven energy management strategy to reduce energy bills by $32 \%$ or more. By improving energy efficiency, colleges and universities can distinguish themselves as environmental leaders and save money for repair and renovation, hiring of new faculty, new construction, and other core activities. [3]

\section{ENERGY DEMAND IN INDIA}

India is the one of the most populated country in the world and one of the most growing countries in the world. In order to achieve sustainable and continuous growth rate, energy in the usable form plays an important role. From the time of independence, India has raised the power generation capacity from $1200 \mathrm{MW}$ to many folds at present. In every five year planning, energy got significant importance. But the gap between generation and the demand is rising up day by day. The fossil fuel reserve in India is not very vast and may be 


\section{International Journal of Engineering Applied Sciences and Technology, 2019 Vol. 4, Issue 8, ISSN No. 2455-2143, Pages 331-333 \\ Published Online December 2019 in IJEAST (http://www.ijeast.com)}

depleted totally by the middle of the century which indicates an alarm situation of near future. [1]

Furthermore, Demand for Oil was transited to Electricity due to the expansion of industrialization. About $60 \%$ of electricity energy had been consumed by this sector. Indeed, India has possessing good and sufficient natural resources which possible to renewal, if the consumption trends will run with the same ratio the non-renewable resources of oil for around 25 years, natural gas 55 years and coal 180 years only can sustain because, by 2050 the global population possibility to attain 8 billion and use of total energy has increasing around 330 per cent on 1990-2020.[2].Sector wise demand is shown in table below: [1][4]

\begin{tabular}{|l|l|l|}
\hline $\begin{array}{l}\text { Sr. } \\
\text { No. }\end{array}$ & Sectors & $\begin{array}{l}\text { Percentage of total } \\
\text { consumption }\end{array}$ \\
\hline 1. & Education & $2 \%$ \\
\hline 2. & Commercial & $20 \%$ \\
\hline 3. & Industrial & $29 \%$ \\
\hline 4. & Transportation & $30 \%$ \\
\hline 5. & Domestic & $19 \%$ \\
\hline \multicolumn{2}{|c|}{ Table 1. Energy distribution }
\end{tabular}

\section{IMPACT ON ENVIRONMENT DUE TO LARGE PRODUCTION OF ENERGY}

A power plant can affect the environment by its construction and by its operation. These effects, or impacts, can be either temporary or permanent. A power plant and its auxiliary components (e.g. natural gas pipelines, water intakes and discharge, coal delivery and storage systems, new transmission lines and waste disposal sites) take up space on the ground and in the air, use water resources, and, in many cases, emit pollutants into the air.[4] The plant's footprint on the ground eliminates opportunities for others to purchase or use the land. It can also affect the existing or future uses of adjoining and nearby land parcels. A coal-fired plant includes some relatively tall buildings and high exhaust stacks. The plant's height may result in safety concerns for aircraft or visual impacts for local landowners. [4] If the land to be used for the power plant is a "greenfield", an undeveloped parcel with mostly vegetation (crops, pasture, or old-field vegetation), there would be impacts on land use, soils, and wildlife present on the site.

A variety of solid wastes can be produced, and these must be handled. The combustion of coal creates ash as a solid waste. Nuclear power plants create spent nuclear fuel rods and lowlevel radioactive wastes. Power plants that use water to create steam or for cooling must filter and purify the water before discharging to surface water. The filtered solids are a byproduct that must be disposed appropriately.[5] Power plant generated SO2 has been a cause of acid precipitation, commonly known as "acid rain," which can damage vegetation and acidify lakes. Species vulnerable to acidic conditions have trouble reproducing and, in some cases, die.[5]
Thermal Power Plant affects environmental segments of the surrounding region very badly. Large amount of SOx, NOx $\&$ SPM are generated which damage the environment and are highly responsible for deterioration of health of human beings, animal kingdom as well as plants. Emission of SPM \& RSPM disperse over $25 \mathrm{Kms}$ radius land and cause respiratory and related aliments to human beings and animal kingdom.[6]

The exposure of employees to high noise levels is very high in the coal based thermal power plant. Moreover, the increased transportation activities due to the operation of the power plant leads to an increase in noise levels in the adjacent localities.[6]

\section{CASE STUDY: HEALTHY WAY TO SAVE ELECTRIC ENERGY}

Taking the advantage of old good saying "Early to bed, Early to rise", the study is being done in Engineering Institute especially in the hostel premises where taking advantage of a healthy habit, saving of energy can be done without any social or environmental issues or impacts. This way can also be implemented to the houses and living areas. There is no cost of implementation to be paid and also no electric equipment is going to be replaced or withdrawn. The concept is laid down to utilize maximum energy of nature which is free of cost and no environmental pollution is created throughout.

Starting with the hostel and calculation of total yearly saving is done here.

Total no. of rooms in the hostel $=118$

Mercury lamp in a room $=02$ (36 watt each)

Total lamps in the hostel $=236$

Total watts in the hostel $=236 * 36=8496$ watt

Now if students get motivated to change their sleeping hours from 12 pm - 08 am to 10 pm - 06 am then we can save atleast 02 hours usage of electricity during summer and can save 01 hours usage of electricity during winters.

Total saving of Energy per year $=2 \times 8496 \times 6 \times 30+$ $1 \times 8496 \times 6 \times 30=4587840=4588 \mathrm{kWh}$

Rate of electricity per $\mathrm{kWh}=8.16 /$ - (approx.)

Total saving of money per year $=4588 \times 8.16=37438 /-$

This saving is totally independent of any cost in terms of environment, social and health. Any additional cost is required so far for execution of this methodology

\section{OTHER WAYS TO SAVE ELECTRICITY}

The costs of energy-saving measures have been a critical barrier in its implementation (Sardianou, 2008). For customers to invest in energy-saving equipment's subsidy plays a major role (Jaffe and Stavins, 1994). 


\section{International Journal of Engineering Applied Sciences and Technology, 2019 \\ Vol. 4, Issue 8, ISSN No. 2455-2143, Pages 331-333 \\ Published Online December 2019 in IJEAST (http://www.ijeast.com)}

The costs of energy-saving measures have been a critical barrier in its implementation. For customers to invest in energy-saving equipment's subsidy plays a major role.

\section{Low-Cost Measures-}

- Measure and track energy performance inside the buildings.

- Switch off lights when not in use or when natural daylight is available.

- Schedule timely and regular maintenance of heating and cooling equipment to guarantee efficient operation.

- Educate students and staff about how their behaviours affect energy use on campus, particularly in residence hall settings.[3]

\section{Cost-Effective Investments-}

- Upgrade and maintain heating, cooling and other electrical equipment for giving better efficiency during operation.

- Install energy-efficient lighting systems and controls that improve light quality and reduce heat so that to protect environment also.

- Installed Sub-meter into campus buildings so that energy use can be more accurately measured and tracked to work on it.

- $\quad$ Remain in contact with an energy services provider to help manage and improve energy performance.

- Use energy-efficient electrical products like ENERGY STAR qualified office equipment.

- Use window films and cover with insulation or reflective roof coating to reduce energy consumption.[3]

\section{CONCLUSION}

The primary concern of everyone in the society is to save energy in any form so that to correlate one's future with possible available energy resources. This methodology will help those who are committed to protect environment with zero cost.

Other ways can also be helpful for the purpose of energy saving but no doubt; some additional cost has to be paid as compensation (in maintenance or replacement).

Coal is primary material used for production of electricity in thermal power plants, which is a releasing agent of $\mathrm{CO}$ and $\mathrm{CO}_{2}$. Some other gases also released and solid waste is generated in a large amount (major cause of water pollution).

A healthy habit of being "early to bed and early to rise" can give a zero cost saving of energy with no environmental and social impacts. This will also leads students to have a good health.

Same process can be applicable on other residential apartments or campuses so that to save maximum energy and to utilise natural light.

\section{REFERENCES}

[1] Biswas Biswajit, Mukherjee Sujoy, Ghosh Aritra, Conservation of Energy: A Case Study on Energy Conservation in Campus Lighting in an Institution, International Journal of Modern Engineering Research (IJMER) www.ijmer.com Vol.3, Issue.4, Jul - Aug. 2013 pp1939-1941 ISSN: 2249-6645.

[2] Amose T., Dr. Jeyakumar K.R., A Study on Major Commercial Energy Consumption in India, IOSR Journal of Economics and Finance (IOSR-JEF) Volume 7, Issue 6 Ver. II (Nov. - Dec. 2016), PP 11-15.

[3] Higher Education: An Overview of Energy Use and Energy Efficiency Opportunities, www.energystar.gov/highered

[4] Khare Vivek, Bhargava Ashish, Mishra Priyanka, Estimation of Generation Cost of Electricity at $500 \mathrm{MW}$ Thermal Power Plant, International Journal of Scientific Research Engineering \& Technology (IJSRET), Volume 7, Issue 4, April 2018.

[5] Environmental Impacts of Power Plants, Public Service Commission of Wisconsin Website: http://psc.wi.gov/

[6] POKALE W. K., EFFECTS OF THERMAL POWER PLANT ON ENVIRONMENT, Sci. Revs. Chem. Communication: 2(3), 2012, 212-215 ISSN 2277-2669.

[7] Sony Michael, Mekoth Nandakumar, A qualitative study on Electricity Energy-Saving behaviour, Management of Environmental Quality: An International Journal June 2018 DOI: 10.1108/MEQ-02-2018-0031.

[8] Panna R., Thesrumluk R. and Chantrapornchai C., Development of Energy Saving Smart Home Prototype, International Journal of Smart Home Vol. 7, No. 1, January, 2013

[9] Bhukya Prasad, Dr. Basak Debasish, Energy Saving Technologies in Industries- An overview International Journal of Scientific and Research Publications, Volume 4, Issue 4, April 20141 ISSN 2250-3153

[10] Banerjee Reshmi, Importance of Energy Conservation, International Journal of Innovative Research in Advanced Engineering (IJIRAE) ISSN: 2349-2163 Issue 4, Volume 2 (April 2015)

[11] Mr. Nadaf S. N. * , Mr. Burali Y.N., Importance of Energy Conservation, International Journal of Engineering Science Invention ISSN (Online): 2319 - 6734, ISSN (Print): 2319 - 6726 Volume 2 Issue 5 || May. 2013 || PP.44-52

[12] www.google.com/images 